\title{
Exploring the past of Mavrovouni forest in the Pindus Mountain range (Greece) using tree rings of Bosnian pines
}

\author{
Anastasia Christopoulou ${ }^{1,2}\left(\right.$ Nikolaos M. Fyllas $^{3} \cdot$ Barbara Gmińska-Nowak $^{1} \cdot$ Yasemin Özarslan $^{4}$. \\ Margarita Arianoutsou ${ }^{2} \cdot$ Robert Brandes $^{5} \cdot$ Tomasz Ważny $^{1}$
}

Received: 24 February 2021 / Accepted: 26 July 2021 / Published online: 10 August 2021

(c) The Author(s) 2021

\begin{abstract}
Key message Long Bosnian pine chronologies from different mountains are shaped by different climatic parameters and can help identify past drought events and reconstruct landscape histories.

Abstract We developed a 735-year-long Pinus heldreichii chronology from the southern distribution limit of the species, expanding the available database of long Bosnian pine chronologies. Tree-ring growth was mainly positively correlated with growing degree days (GDD: $r_{1950-2018}=0.476$ ) while higher temperatures during both winter and growing season also enhanced growth ( $T_{\mathrm{WT}}: r_{1950-2018}=0.361$ and $T_{\mathrm{GS}}: 0.289$, respectively). Annual precipitation, during both calendar and water years, had a negative but weaker impact on annual tree growth. The newly developed chronology correlates well with chronologies developed from the neighboring mountains. The years with ring width index (RWI) lower than the average were found to correspond to cool years with dry summers. Still, the newly developed chronology was able to capture severe drought events, such as those in 1660, 1687, and 1725. Several old living trees had internal scars presumably caused by fires. Therefore, old mature trees could be used for fire history reconstruction in addition to climate reconstruction. Although the presence of lightning scars indicates an important natural agent of fire ignition, human activities associated with animal grazing could also be an underlying reason for fires in the region.
\end{abstract}

Keywords Dendrochronology $\cdot$ Pinus heldreichii $\cdot$ Tree-ring width $\cdot$ Ring width index $\cdot$ Climate impact

Communicated by Leavitt .

Anastasia Christopoulou

anchristo@umk.pl; anchristo@biol.uoa.gr

1 Centre for Research and Conservation of Cultural Heritage, Faculty of Fine Arts, Nicolaus Copernicus University, 87-100 Toruń, Poland

2 Department of Ecology and Systematics, Faculty of Biology, National and Kapodistrian University of Athens, Panepistimiopolis, 15784 Athens, Greece

3 Biodiversity Conservation Lab, Department of Environment, University of the Aegean, 81100 Mytilene, Greece

4 Department of Archaeology and History of Art, Koç University, 34450 Istanbul, Turkey

5 Geographer and independent consultant, Geuschmidstr. 8, 90480 Nuremberg, Germany

\section{Introduction}

Development of long, well-replicated tree-ring chronologies has considerably contributed not only to the reconstruction of past climate (Fritts 1976; Cook and Kairiukstis 1990; Esper et al. 2016, 2020), including the identification of major historical drought events (e.g. Cook et al. 2010, 2015, 2016, 2020; Touchan et al. 2005b, 2014a, 2014b; Morales et al. 2020), but also to the reconstruction of disturbances (Bergeron et al. 2002) such as fires (e.g. Baisan and Swetnam 1990; Fulé et al. 2008; Keane et al. 2008; Christopoulou et al. 2013; Molina-Terrén et al. 2016; Amoroso et al. 2017; Mazarzhanova et al. 2017; Harley et al. 2018). Tree-ring chronologies have also been used to understand the response of tree growth to climatic variability (Fritts 1976) and to predict how forests might respond to climatic change (Williams et al. 2010; Fyllas et al. 2017a). Thus, a sound understanding of past climate and tree-growth interactions is important, particularly given the global increase in the frequency of widespread severe droughts, as well as the intensity of 
drought events during the recent decades (Cook et al. 2016; Morales et al. 2020). This is becoming even more important in areas such as the Mediterranean region, identified as particularly sensitive to climatic changes (Touchan et al. 2005b; Esper et al. 2020).

Dendrochronologists tend to look for very old tree stands with individuals living for several centuries, which may contribute to high-resolution paleoclimate reconstructions (Klippel et al. 2017). The tree species commonly used for climate reconstruction in Greece is Pinus heldreichii Christ (Touchan et al. 2005b, 2014a, 2014b; Klippel et al. 2017, 2018; Esper et al. 2020, 2021) since it forms very old stands, including also the oldest scientifically-dated tree in Europe (Konter et al. 2017; Piovesan et al. 2018). P. heldreichii or Bosnian pine is endemic to the high mountains of the Balkans and Southern Italy. It grows between 800 and $2600 \mathrm{~m}$ (a.s.l.) and reaches its southernmost geographical limit of expansion at ca. $40^{\circ}$ latitude in Italy on Monte Pollino and in Greece on Mt. Olympus as well as the northern Pindus where it also forms the treeline (Brandes 2007; Vitali et al. 2019).

Numerous dendrochronological studies have been performed with Bosnian pine over the Balkan Peninsula and Italy, most of which focus on the species' response to climatic variability (Todaro et al. 2007; Panayotov et al. 2010; Seim et al. 2012; Klippel et al. 2017) and anthropogenic activity (Todaro et al. 2007). Long tree-ring chronologies have also been used for climate reconstruction (Touchan et al. 2005b, 2014a, 2014b; Trouet et al. 2012; Klesse et al. 2015; Klippel et al. 2018; Esper et al. 2020, 2021). An application of blue intensity, a relatively new measurement technique based on image analysis used as a proxy for treering density (Campbell et al. 2007; Buckley et al. 2018), illustrated positive correlations with August and AugustJuly temperatures in Bosnian pines as shown by Tsvetanov et al. (2020). P. heldreichii in Greece has been studied dendrochronologically on Mt. Olympus (Touchan et al. 2014a; Klesse et al. 2015) and the Pindus Mountain range (Touchan et al. 2005b; Esper et al. 2021), particularly on Mt. Smolikas and Valia Kalda, providing insights into the long-term hydroclimatic variability in the northeastern Mediterranean (Klippel et al. 2017, 2018). Recent June-July precipitation reconstructions are based on the standardized precipitation index (SPI) (Klippel et al. 2018; Esper et al. 2021), a widely used index to characterize meteorological droughts on a range of timescales.

On the other hand, the population dynamics of Bosnian pine forests and their response to natural disturbances such as fires have been poorly studied. To the best of our knowledge, there is only one study from the Pirin Mountains in Southwestern Bulgaria where tree-ring cores were used to date past fire events (Vasileva and Panayotov 2016). In most cases fire history reconstruction is based on fire scars analysis using cross-sections and partial cross-sections collected from dead or living trees, respectively (e.g., Baisan and Swetnam 1990; Brown et al. 1999; Fulé et al. 2008; Christopoulou et al. 2013; Cerano-Paredes et al. 2020). Nevertheless, conducting such research on Bosnian pines is challenging since most of them are found on relatively steep slopes and at high altitudes, primarily within the borders of protected areas where collection of cross-sections is neither easy nor always permitted.

In this study we developed an independent chronology from the southern distribution limit of Bosnian pine. Our primary goal was to study the Mavrovouni forest and Bosnian pines as a biological archive and a source of environmental information by extracting the signals registered in tree rings. We also tried to answer the following questions: (i) which climate predictors of tree-growth are the best for this species?, (ii) do the known key drought periods of the past, as identified from other studies in the region, emerge in our independent chronology?, (iii) is it possible to use the samples collected for the development of a local chronology to also identify disturbances such as fires?, and (iv) is there a potential for dating historical wood with our developed chronology?

\section{Materials and methods}

\section{Study area and field sampling}

The study area falls within the borders of the Northern Pindus National Park (northwestern Greece), the largest terrestrial national park in Greece, covering an area of $2000 \mathrm{~km}^{2}$. The Park hosts the second-highest mountain in Greece, Mt. Smolikas (2637 m a.s.l.), as well as other mountain ranges, such as Tymfi, Lygkos, Vasilitsa, and Mitsikeli. The geological and geomorphological values of the Pindus Mountain range formations have been recognized by UNESCO; therefore, the Park is a member of the European and Global Geoparks' Network. It is also part of the European (Natura 2000) network of protected areas (Management Agency of Vikos-Aoos and Pindus National Park 2017). Stands of Pinus heldreichii, Pinus nigra J. F. Arnold, Fagus sylvatica L., Abies borisii-regis Mattf. and Quercus spp. form the dominant forest types in the region. Old trees can be found scattered across natural forest stands (Brandes 2007; Touchan et al. 2012).

The study site represents the southern distribution limit of Bosnian pine, located $9 \mathrm{~km} \mathrm{~N}-\mathrm{NW}$ of Metsovo, a wellknown and large Vlach village whose shepherds once had thousands of sheep grazing over the Pindus mountains (McNeill 1992), and at a short distance from the Aoos Springs artificial lake (Fig. 1). P. heldreichii forms the timberline while in lower altitudes $P$. nigra (black pine) 
Fig. 1 Location of the study area and the sampled trees. The forests with $P$. heldreichii (habitat type 95A0) within the Natura 2000 network across the broader region are also shown

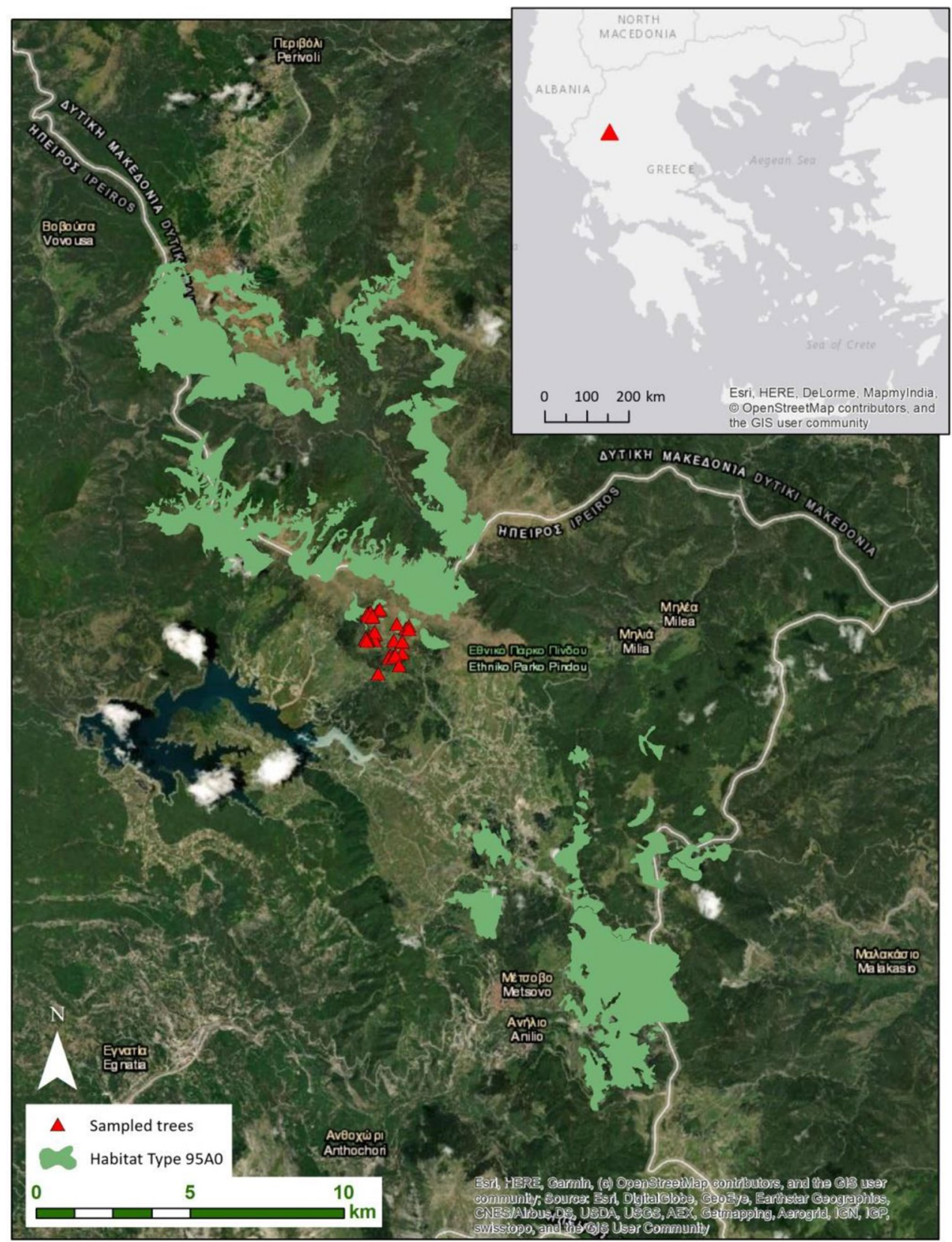

is more abundant with mixed stands of the two species found at intermediate altitudes. The summit where field measurements and sampling took place is called Mavrovouni. Mavrovouni in Greek means "black mountain", a name attributed to either the dominance of black pine at lower altitudes, or the black colour of the mountain after fire, as suggested by local foresters. Another possible explanation for this place name, a frequently used word for Greek mountains, could be that the study area was a formerly densely tree-covered mountain. The sampling area is characterized by the presence of living old and young trees, snag, downed logs, and stumps widely scattered in the open landscape while pine seedlings and saplings are abundant in the understory. The basement rock is flysch, and the soil cover is discontinuous with ground vegetation mostly consisting of grasses and other perennial herbs. The remnants of standing trees burnt by lightning are abundant (Fig. 2). In 2018 and 2019, a total of 100 samples were collected from 43 living and 2 dead $P$. heldreichii trees. The mean diameter at breast height of the sampled trees was $130.5 \mathrm{~cm}$. At least two cores per tree were extracted from each individual to minimise the impact of reaction wood. From trees hit by lightning, cores were collected from the part of the trunk that was not obviously damaged. Sampling was performed with the use of increment borers long enough to obtain a complete radius 


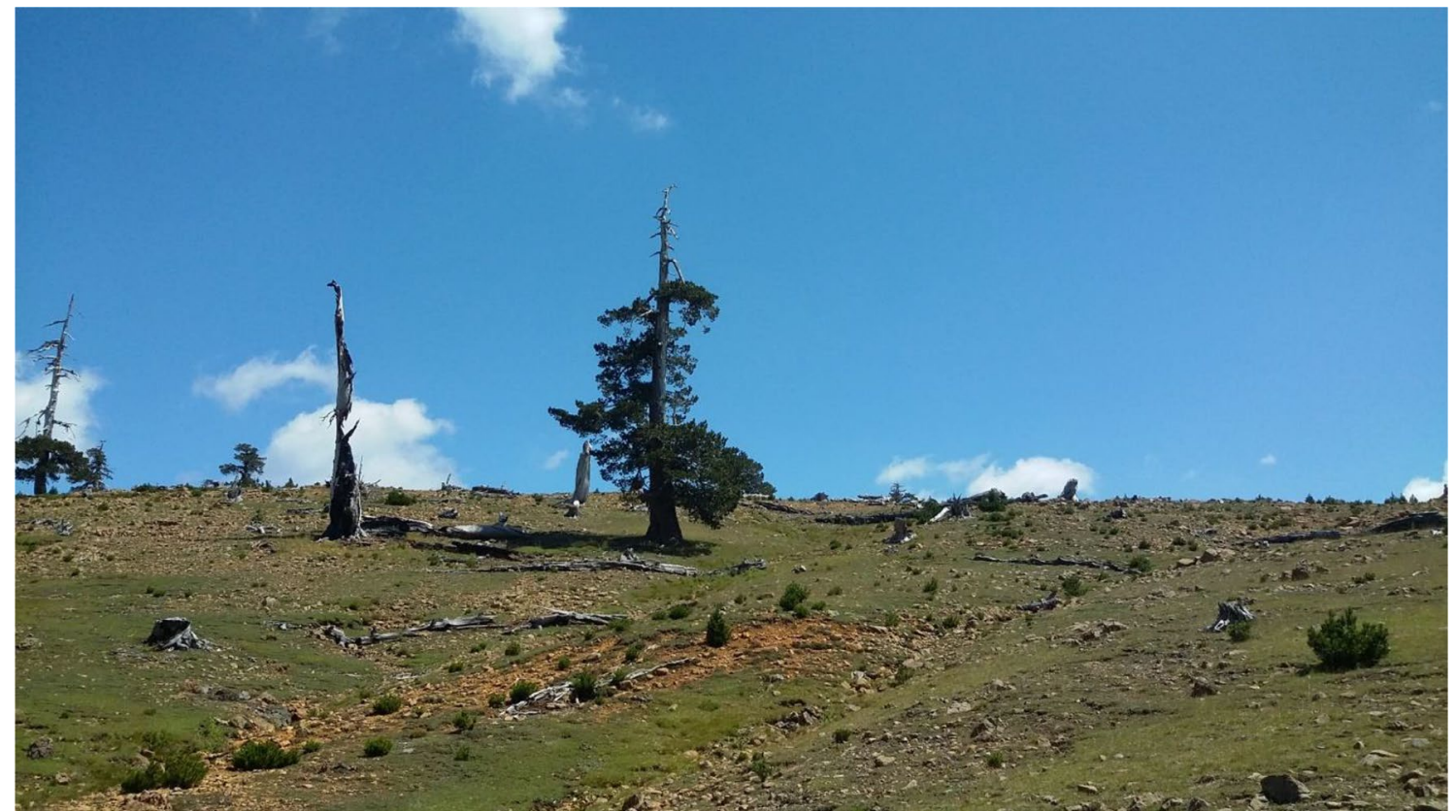

Fig. 2 View of the study area with old isolated standing trees, remnants of burnt trees, and natural regeneration of Pinus heldreichii

of the trunk to reach the pith, with the longest one having a length of $800 \mathrm{~mm}$. From dead trees, cross-sections were cut with a chainsaw.

Trees were sampled from elevations ranging from 1650 to $2000 \mathrm{~m}$ a.s.l. (mean $1900 \mathrm{~m}$ a.s.1.) while the mean slope was $18^{\circ}$, varying from 9 to $36^{\circ}$. Samples were collected from all sides of the summit. Local temperature data were obtained from three data loggers placed during the first field survey in 2009. Two of these were buried in the soil at a depth of $15-20 \mathrm{~cm}$ while the third one was placed inside a tree to measure air temperature. The recording period lasted until January 2019.

\section{Laboratory methods: samples preparation, measurements, and crossdating}

In the laboratory, all samples (cores and slices) were properly prepared with the use of razor blades and/or progressively finer grade abrasive paper to have tree rings and xylem cells clearly visible under magnification. Treering width was measured to $0.01 \mathrm{~mm}$ using Time Series Analysis and Presentation software (TSAP-Win) (Rinn 2011) and a LINTAB (Rinntech Inc. Heidelberg, Germany) measuring table. All samples were visually and statistically crossdated using TSAP-Win to identify the possible presence of missing or false rings (Stokes and Smiley 1996). Moreover, the samples were analyzed to detect scars caused by fire or other types of disturbances.

\section{Climate data}

Data from the data loggers were used to (i) obtain an overview of weather patterns and (ii) to numerically define a "winter", a "summer" and a "growing" season period. By estimating the monthly climatic profile of the area, we identified the period in which mean monthly temperature is lower than $0{ }^{\circ} \mathrm{C}$ (December, January, February, and March) and designated it the "winter" period. We also identified the "growing season" period (May-October) when monthly mean temperature is greater than $5{ }^{\circ} \mathrm{C}$, and the "summer" period (June-August) when mean temperature is greater than $10{ }^{\circ} \mathrm{C}$. Data loggers placed in the soil informed us about the snow cover period. Snow cover helps prevent the soil from freezing and stabilizes the ground temperature (Zhang 2005). Based on the data derived from the data loggers buried in the soil, the snow cover period lasts from December to March, overlapping with designated "winter" period.

Longer term climate data (1950-2018) were obtained from the European Climate Assessment (ECAD) gridded dataset (E-OBS), including daily mean, minimum and maximum temperature, daily total precipitation, and solar radiation data (after 1980). These data were extracted at a 0.1-degree resolution (ca. $10 \mathrm{~km}$ ) and corrected using a lapse rate of $6.5^{\circ} \mathrm{C} \mathrm{km}^{-1}$ based on the elevation difference between the E-OBS digital elevation model and the GPS readings of actual site elevations (Fyllas et al. 2017b). No elevation adjustment was made for precipitation due to the 
restricted data availability for the precipitation lapse rate for the study area.

\section{Statistical analyses}

Standardization of the crossdated tree-ring series was performed to remove the age-related growth trend and other low-frequency variations (Cook and Kairiukstis 1990) by fitting a negative exponential curve and estimating an annual ring width index (RWI). The dimensionless RWI was computed by dividing the observed raw ring-width value by the fitted value of the negative exponential curve. This is a commonly used method preserving high-frequency variation of a shorter duration than the length of the individual series (Sullivan et al. 2016). A mean chronology was developed using the detrended dataset constrained to years having an adequate sample depth ( $>10)$, i.e., years where mean RWI was estimated by more than ten different tree rings. In our dataset this period extends from 1515 to 2018 with a mean expressed population signal EPS $=0.92$, suggesting a sufficiently replicated chronology (Wigley et al. 1984). Extreme years (either bad or good) in terms of RWI were identified from the 2.5 and 97.5 percentiles of the mean chronology. The developed mean chronology was assessed against the existing chronology from the broader area available in the International Tree-Ring Data Bank-ITRDB (Klippel et al. 2018), based on visual and statistical crossdating with the use of TSAPWin. We also calculated the Pearson correlation coefficients between our mean chronology and the mean chronology developed by Klippel et al. (2018).

Pearson correlation coefficients were also computed between annual RWI and calendar year, water year (from previous October to current September), growing season (May-October), winter (previous December to current March), and summer (current June-August) mean temperature $T_{\mathrm{X}}$, precipitation $\left(\mathrm{P}_{\mathrm{X}}\right)$, and incoming radiation $\left(\mathrm{Q}_{\mathrm{X}}\right)$. Correlation coefficients were also estimated for the summer months covering June-July and April based on Klippel et al. (2017)'s study, which has shown that they were significantly correlated with tree-ring width (TRW) from Mt. Smolikas. Therefore, X indicates either WY: water year, CY: calendar year, GS: growing season, WT: winter, SM: summer, JJ: June-July or Ap: April. The number of growing degree days (GDD), a commonly used heat index, defined from mean daily temperature $\left(T_{i}\right)$ as $G D D=\sum_{i=1}^{i=365}\left(T_{i}-5\right)$ per water year, was also estimated and used as a predictor of RWI.

In order to explore the relationship between the detected extreme years and climate, we combined our detrended chronology with the SPI chronology developed by Klippel et al. (2018). We used our detrended chronology particularly to identify warm years (defined as those years with RWI > average RWI) and cool years (RWI < average RWI) (see Sect. 3.2), and the reconstructed summer SPI data series to identify wet $(\mathrm{SPI}>0)$ and dry $(\mathrm{SPI}<0)$ years. We then estimated a consistency table by identifying extreme years during this four-way classification and subsequently ran a chi-square test to see the difference in extreme years between summer wet and dry years.

All analyses and visualisations were made with R (R Core Team 2020) using the dplR (Bunn et al. 2020), the lubridate (Grolemund and Wickham 2011), the tidyverse (Wickham 2017), the MASS (Venables and Ripley 2002), the SPEI (Beguería and Vicente-Serrano 2017), and the ggpubr (Kassambara 2017) packages.

\section{Results}

\section{Chronology characteristics}

The newly developed chronology, consisting of 45 dated trees, is 735 years long (1284-2018). The average series length is 396 years and the mean series intercorrelation (MC) is $0.569( \pm 0.092)$. Our analysis was restricted to the period between 1515 and 2018 when we had a sufficient sample depth (number of trees $>10$ ) and EPS $\geq 0.85$. In the mean chronology there was an apparent age effect (Fig. 3, Fig. S1) removed after detrending (Fig. 3). In both chronologies an increase in the annual tree-ring growth was observed during the past 20 years, while several increases or decreases in tree growth can be detected during the past 7 centuries, the most prominent of which is the decrease in annual growth for the period ca. 1850-1950 (Fig. 3).

The newly developed chronology correlates very well with the existing chronology from Mt. Smolikas [ $t$-value Baillie-Pilcher $($ TVBP $)=20.8$ and $t$-value Hollstein $(\mathrm{TVH})=21.1$; Cross-Dating Index $(\mathrm{CDI})=155$; Gleichlaeufigkeit $(\mathrm{Glk})=74^{* * *}$ ], which had been previously used for hydro-climate reconstruction (Klippel et al. 2018). The Pearson's correlation coefficient between the two chronologies for the overlapping 503 years (1515-2018) was 0.537 $(\mathrm{p}<0.001)$.

\section{Correlation of RWI with climate}

Data from the three data loggers revealed the prevailing temperatures of our study area. The average annual air $T_{\text {mean }}$ was $4.62{ }^{\circ} \mathrm{C}$, slightly higher $\left(5.31-5.40^{\circ} \mathrm{C}\right.$ ) in the soil (Table 1) during the 10-year data record. The average annual air $T_{\text {min }}$ and $T_{\max }$ were $-14.16{ }^{\circ} \mathrm{C}$ and $22.90{ }^{\circ} \mathrm{C}$, respectively, with data from the soil loggers indicating a much smaller temperature range $\left(T_{\min }=-1.4{ }^{\circ} \mathrm{C}, T_{\max }=17.93{ }^{\circ} \mathrm{C}\right)$. A comparison of annual mean air temperatures from the data loggers and the data extracted from the European Climate Assessment E-OBS showed a positive (although not significant) 

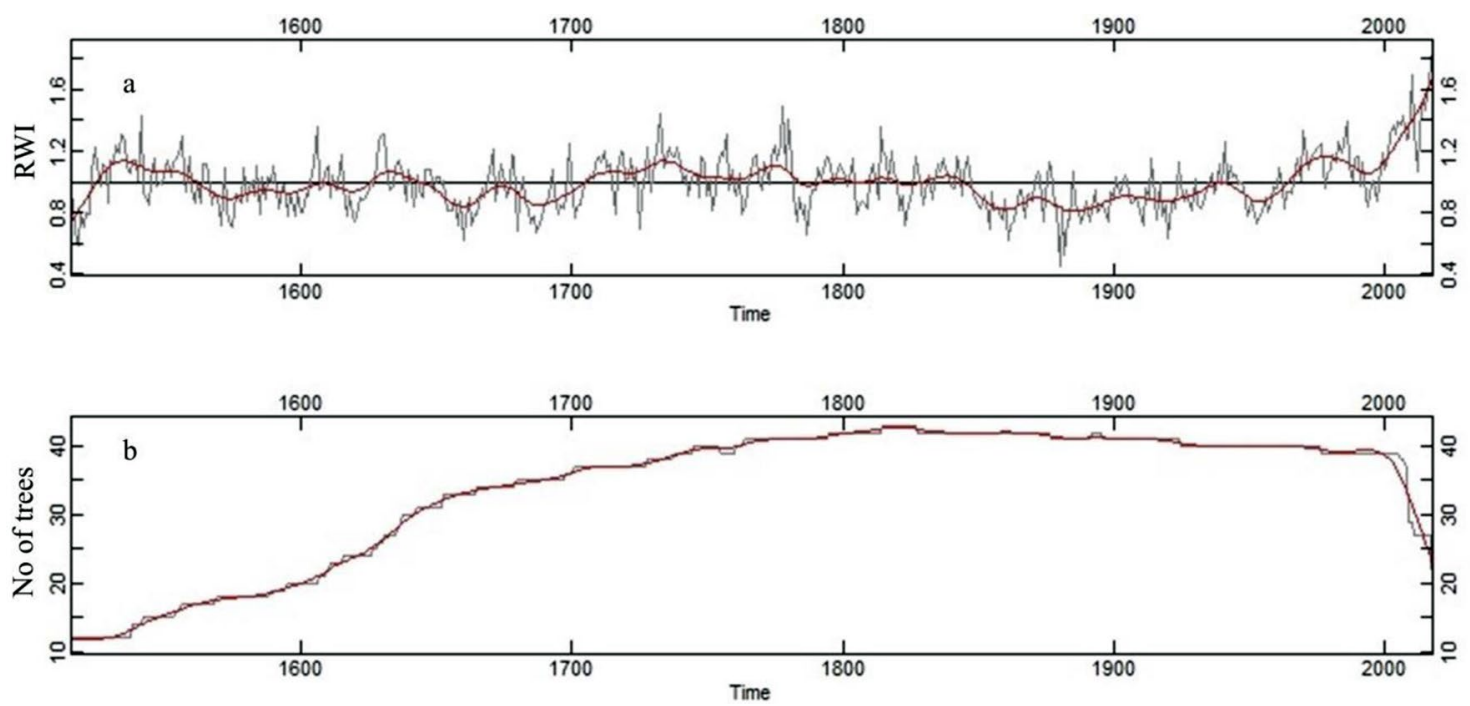

Fig. 3 Detrended mean chronology (a) and sample depth (b)

Table 1 Annual mean temperature data obtained from the local loggers and from the E-OBS

\begin{tabular}{lcccc}
\hline & \multicolumn{2}{l}{ Period 2009-2018 } & Period 1950-2018 \\
\cline { 2 - 5 } Average & $\begin{array}{l}\text { Data logger 1 } \\
(\text { soil })\end{array}$ & $\begin{array}{l}\text { Data logger 2 } \\
\text { (soil) }\end{array}$ & Data logger 3 (tree) & E-OBS data \\
\hline$T_{\text {mean }}\left({ }^{\circ} \mathrm{C}\right)$ & 5.40 & 5.31 & 4.62 & 5.25 \\
$T_{\min }\left({ }^{\circ} \mathrm{C}\right)$ & 0.18 & -1.40 & -14.16 & -15.20 \\
$T_{\max }\left({ }^{\circ} \mathrm{C}\right)$ & 17.93 & 15.24 & 22.90 & 26.62 \\
\hline
\end{tabular}

Table 2 Pearson's correlation coefficients of the examined climatic parameters with annual RWI. Statistically significant values $(p<0.05)$ are shown in bold

\begin{tabular}{lllll}
\hline Period & $T$ & $P$ & $Q$ & GDD \\
\hline Water Year (WY) & $\mathbf{0 . 3 6 6}$ & $\mathbf{- 0 . 2 9 8}$ & 0.007 & $\mathbf{0 . 4 7 6}$ \\
Calendar Year (CY) & $\mathbf{0 . 4 0 6}$ & $\mathbf{- 0 . 3 4 7}$ & 0.029 & $\mathbf{0 . 4 3 0}$ \\
Growing Season (GS) & $\mathbf{0 . 2 8 9}$ & -0.188 & 0.029 & \\
Winter (WT) & $\mathbf{0 . 3 6 1}$ & -0.162 & 0.007 & \\
Summer (SM) & 0.208 & -0.048 & 0.007 & \\
June-July (JJ) & 0.207 & -0.055 & 0.029 & \\
April (Ap) & 0.207 & -0.055 & -0.055 & \\
\hline
\end{tabular}

correlation (Pearson's $r=0.48, p=0.271, N=7$ ). Further tree-growth vs. climate analysis was performed with the E-OBS data that cover a much longer period.

For the 1950-2018 period significant correlations were found for annual RWI with various temperature and precipitation metrics (Table 2). Significant positive correlations were found between RWI and the mean annual temperature of the calendar $\left(T_{\mathrm{CY}}, r=0.406\right)$ and water years ( $T_{\mathrm{BY}}, r=0.366$ ) (Fig. 4). Correlations of RWI were also significant with $T_{\mathrm{WT}}(r=0.361)$ and $T_{\mathrm{GS}}(r=0.289)$.
Annual precipitation was negatively associated with RWI $(\mathrm{PCY}=-0.347, \mathrm{PBY}=-0.298)$ (Fig. 4), while no significant association was found between winter and summer precipitation with tree growth. Incoming radiation did not show any significant association with RWI. However, the highest correlation was observed between RWI and GDD $\mathrm{BY}_{\mathrm{BY}}$ $(r=0.476)$ (Fig. 4), suggesting that the number of growing degree days during the water year is particularly important for the growth of the trees in the study area.

\section{Detection of extreme years}

Since GDD, a commonly used heat index, was the strongest predictor of RWI, we used our mean detrended chronology to identify warm (RWI > meanRWI) and cool (RWI $<$ meanRWI) years. Extreme years, as identified from the 2.5 and 97.5 percentiles of the mean site chronology, during the warm and cool years are illustrated in Fig. 5a. A similar graph, indicating extreme years during the summer wet and dry years, is presented in Fig. 5b. The years with low annual tree-ring growth, as identified from the 2.5 percentile, are also characterized by dry summers, representing drought years, except for 1920. In contrast, all the warm years, as identified from the 97.5 percentile, are characterized by wet 

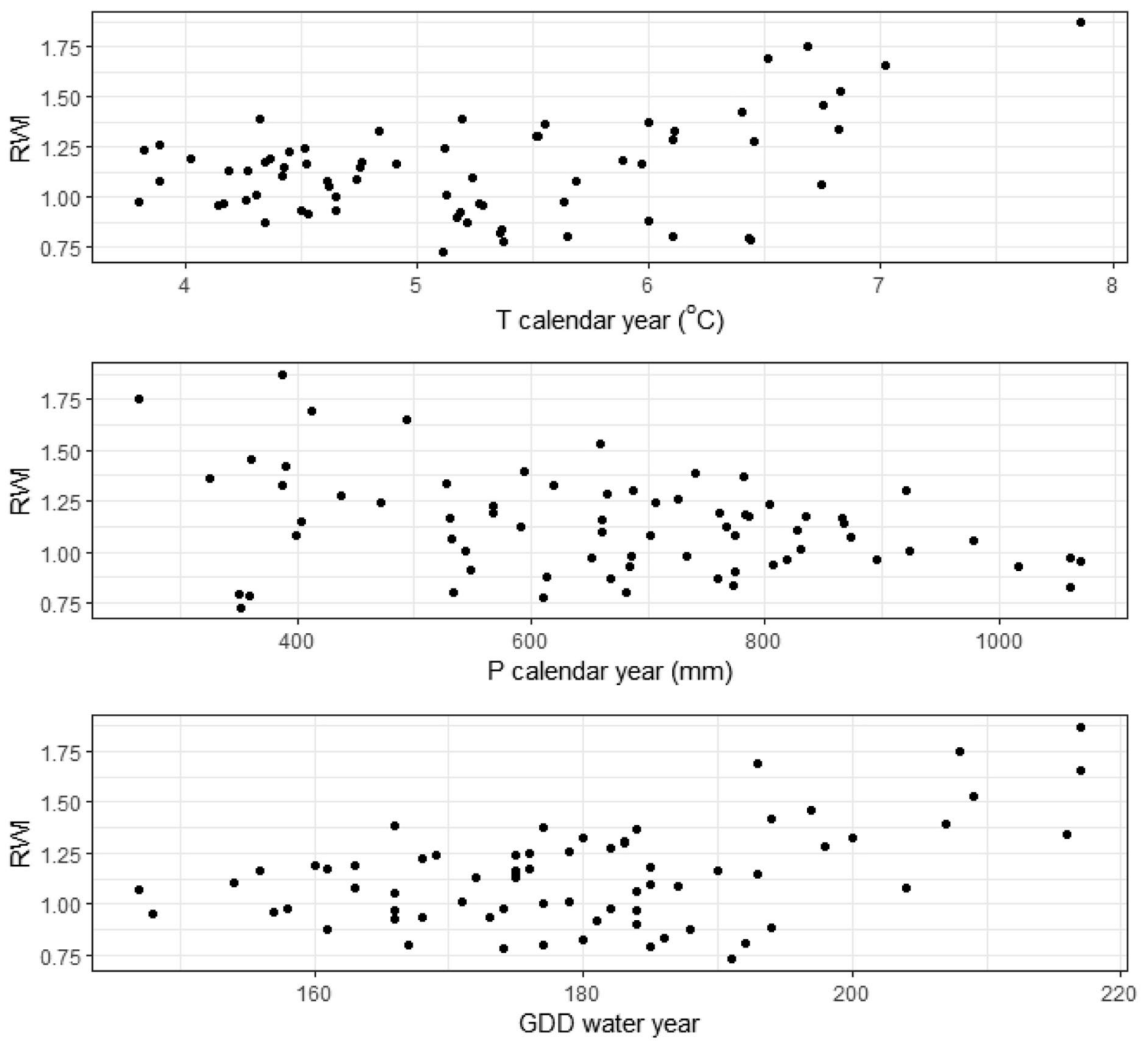

Fig. 4 Tree growth-climate relationships as identified by significant correlations between RWI and $T_{\mathrm{CY}}, P_{\mathrm{CY}}$ and GDD $\mathrm{WY}_{\mathrm{WY}}$

summers. The only exception is 2007 which is characterized by dry summer. In addition to this, 8 out of 13 years with the highest annual growth (Fig. 5a, Table S1), were during the past 2 decades. A $X^{2}$ test indicated a significant difference $\left(X^{2}=12.412, p<0.001\right)$, suggesting that the occurrence of extreme years differ between dry and wet summer years (Fig. 2).

\section{Detection of fire scars}

During the field sampling we noticed that several old trees had signs of lightning scars (Fig. S1) while during the laboratory analysis we detected several internal scars, presumably caused by fires. This is a clear indication that living and dead trees in our study area have great potential for further study on fire history reconstruction. Nevertheless, and due to the small number of partial or complete cross-sections from dead trees and the fact that the method of collecting the cores was not optimal for the detection of fire scars (CeranoParedes et al. 2020) we did not pursue fire history reconstruction in this study.

\section{Discussion}

As in other mountains within the natural distribution of the species, Mavrovouni hosts multi-century-old Bosnian pines. The collected samples contributed to the development of a new long chronology, typical for the species (Klippel et al. 2017). Although the region does not claim to have the oldest living Bosnian pines, it still provides high potential since the climate signal of the developed mean chronology for the last ca. 70 years is relatively high $\left(r_{1950-2018}=0.476\right.$ for GDD) compared to other studies exploring Bosnian pines (Todaro 

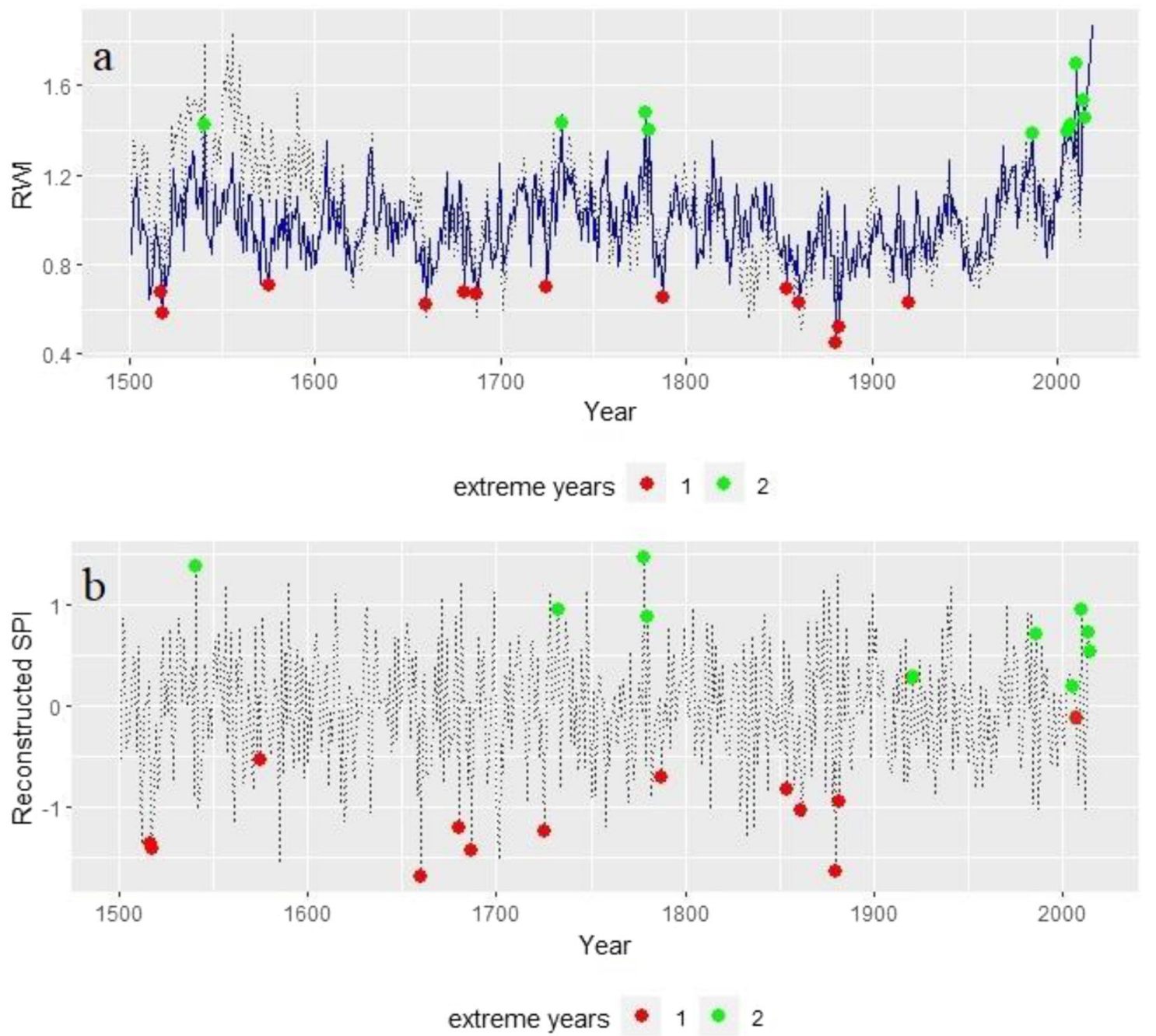

Fig. 5 Extreme years indicated as warm (red)/cool (green) in (a) and summer wet (green) /dry (red) in (b). Warm/cool years are classified based on the RWI vs GDD association. Wet/dry years are classified based on the regional SPI summer reconstruction by Klippel et al. (2018). Blue line represents the detrended chronology developed in

et al. 2007; Panayotov et al. 2010; Seim et al. 2012; Klippel et al. 2017, 2018; Esper et al. 2020, 2021), despite differing results regarding correlations with climate from such studies. The newly developed 735-year-long chronology has potential also for dendroarchaeology and dating of historical timber found in Metsovo and in other Vlach villages founded or expanded between the fifteenth and seventeenth centuries over the northern Pindus.

Both the prolongation of the growing season as expressed by GDD and higher temperatures during the growing season $\left(T_{\mathrm{GS}}\right)$ increased annual growth as previously suggested (Klippel et al. 2017). Warmer winters also had a positive impact on annual growth likely by reducing the stress of winter cold and the period for snow cover and frost (Klippel et al. 2017; Żywiec et al. 2017). The impact of annual temperature (both for calendar and water years) was also the current study while the dashed line represents the detrended chronology developed by Klippel et al. (2018) in Fig. 5a and the reconstructed SPI in Fig. 5b. Dots represent the extreme years as identified from the 2.5 (red) and 97.5 percentiles (green) of the mean site chronology. See also Fig. 6

positive. Despite the strong crossdating between our chronology and the chronology from Mt. Smolikas used for hydroclimate reconstruction (Klippel et al. 2018), our chronology showed a weaker precipitation signal relative to other studies of the broader area (Klippel et al 2017, 2018; Esper et al. 2021). This suggests a greater likelihood that the treering data from our study area could be used for temperature and/or GDD reconstructions, in which case more samples would be needed (e.g., Klippel et al 2017, 2018; Esper et al. 2021), while the possible impact of other factors such as grazing, interspecific competition for soil nutrients, etc. on annual tree growth should be minimized if not excluded. This can be achieved by proper sampling design and selection of appropriate trees (Soltani et al. 2020). In the current study grazing, competition, and other factors could be, together with climate, responsible for the increases and 


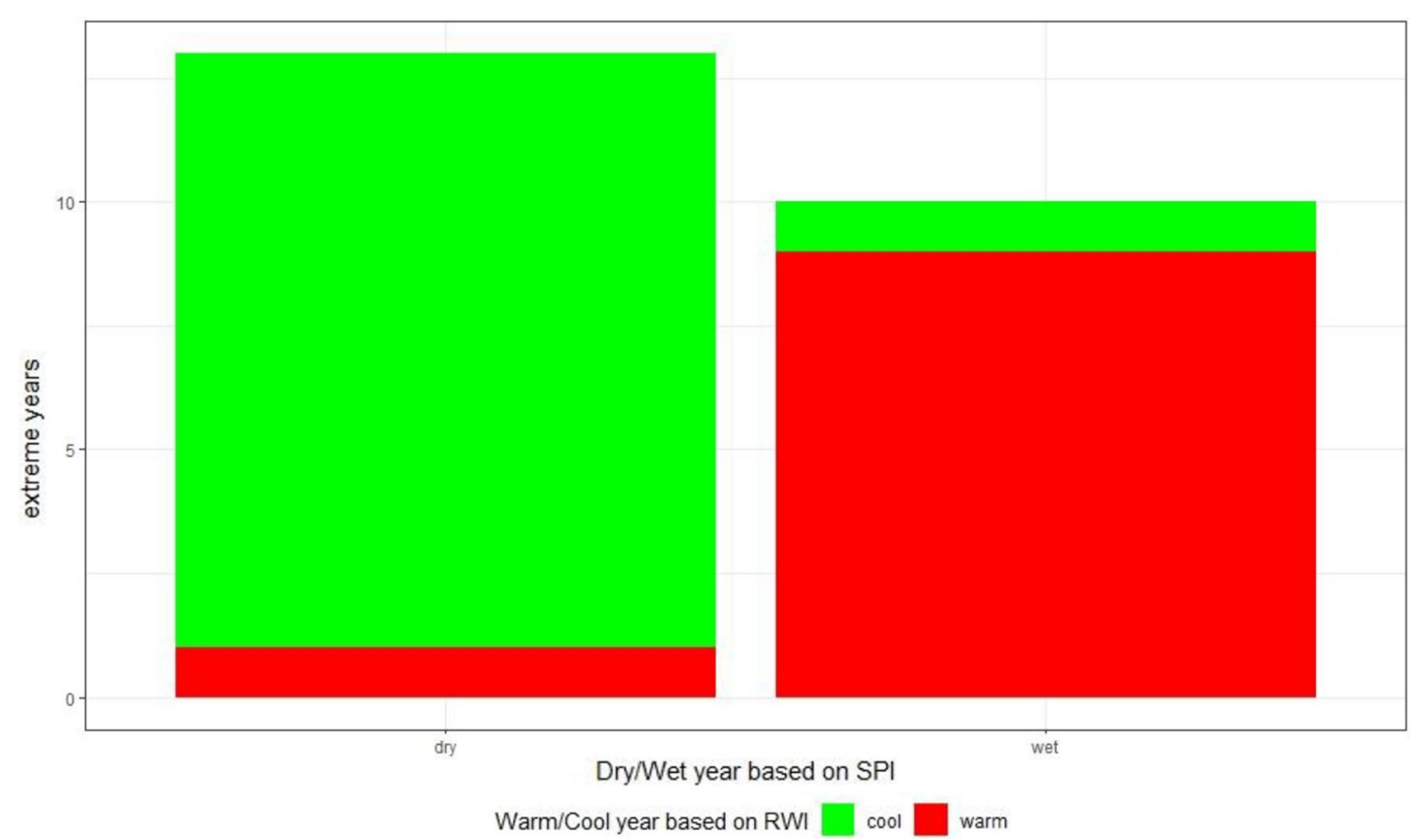

Fig. 6 Extreme years of the developed mean chronology in comparison to warm/cool years with dry/wet summers. A significant $X^{2}$ test indicates differences in the occurrence of extreme years between dry and wet summer years. See text (Sect. 3.3) for details

decreases in growth captured in tree-rings during the past six centuries (Fig. 3). For the period 1950-2018 when our tree-growth climate analysis unfolds, the youngest tree in the dataset was already 150 years old. Therefore, we can assume that most of the trees were sizable enough to be dominant, so their annual growth is less likely to be affected by grazing and inter-tree competition.

The developed chronology captures well-known drought events, such as the year 1660, reported as a catastrophic year in terms of fires and famine for Anatolia (Purgstall 1983) and identified as an extreme dry year in several reconstructions from the broader area (e.g. Kuniholm, 1990; Touchan et al. 2005a, 2005b; 2007; Akkemik et al. 2008), including southern Greece (Brandes 2007, 2009; Klippel et al. 2018). The year 1687 is another known drought year for the Eastern Mediterranean (Akkemik et al. 2005, 2008) while 1725 was described as a year with major drought in Anatolia and Syria (Panzac 1985; Touchan et al. 2007) and detected as an extreme drought year in both the Eastern (e.g., Akkemik et al. 2005, 2008; Brandes 2007, 2009; Touchan et al. 2007; Levanič et al. 2013; Klippel et al. 2018) and Western Mediterranean (Tejedor et al. 2016). Our mean chronology also captures the dry conditions of the mid-nineteenth century (Esper et al. 2021). From the detected wet years, 2007 is the only year also characterized by a dry summer. 2007 was one of the worst years in the recent history of Greece in terms of forest fires causing losses of humans, forests, animals and arable land (Sarris et al. 2014; Christopoulou et al. 2019).
The wetter conditions during 2007 may have led to increased aboveground biomass production, as expected for dry ecosystems (Golodets et al. 2013) while the dry summer period could have led to drier fuel conditions and an associated higher fire risk, including an increased number of ignitions because of lightning fires (Flannigan et al. 2015).

During the twenty-first century the mean chronology and many of the sampled trees show a considerable increase in annual growth, as documented for Bosnian pines on the Pollino massif in Italy (Piovesan et al. 2018) while, according to Esper et al. (2020)'s warm-season temperature reconstruction, the more recent 1985-2014 period was the warmest 30 -year interval since $730 \mathrm{CE}$. Several dendrochronological studies on different species at higher altitudes have revealed an increase in annual growth associated with climate change during the recent decades (e.g., Briffa et al. 2008; Borgaonkar et al. 2010; Dulamsuren et al. 2017; Pretzsch et al. 2020). P. heldreichii radial growth has been reported to be favored by higher temperatures and low precipitation (Todaro et al. 2007). This, together with the prolongation of the growing season (Liu et al. 2018), seems to be the case with the trees of Mt. Mavrovouni adapting to changing climatic conditions despite their old age (Piovesan et al. 2018). Some of these old living trees could be characterized as ancient or veteran, depending on their age, dimensions, and other characteristics, such as the loss of apical dominance and the shape of the crown (Fig. 2). An ancient tree is considered as old based on the species' life cycle and 
typical life expectancy (Fay and Berker 2018) while veteran trees refer to old trees having a large diameter that offer suitable microhabitats for plants and animals of local biodiversity (Horák 2017). Both ancient and veteran trees are of paramount importance for their high biodiversity values and their conservation can help promote further development of ecotourism within the borders of the Northern Pindus National Park.

The physiognomy of the tree stands at Mavrovouni is in accordance with the tree patterns seen on most mountaintops of the Valia Kalda and Smolikas regions neighbouring our study area to the north (Touchan et al. 2005b; Brandes 2007; Klippel et al 2017, 2018; Esper et al. 2020, 2021). Tree individuals are widely scattered in the landscape. Remarkable is the widespread presence of dead wood, an unusual phenomenon for the Greek high mountains (Brandes 2007). Previous dendrochronological research has revealed that the dead wood can be very old with tree-ring series reaching back as far as the sixth century (Klippel et al. 2017). Most likely the very resinous wood of $P$. heldreichii and the dry, often rocky ground surface, both preventing the trunks from quickly decaying, explain this phenomenon. This remarkable physiognomy of the high-altitude Bosnian pine tree stands in the northern Pindus could be explained theoretically by poor regeneration and solitary trees growing up in a widely dispersed pattern. However, it is more likely that the present situation is mainly the consequence of a thinning of formerly denser tree stands, by a combination of grazing and active human tree-removal. This impact seems to have aggravated the microclimatic conditions in the now open stands and made tree regeneration at high altitudes difficult. Today, seedlings, saplings, and an increasing number of young trees are distinctly visible in the area, probably because grazing of the area has stopped or markedly diminished.

The Mavrovouni area seems to have been subjected to heavy grazing by the flocks of sheep and goats of the Vlach shepherds (transhumance). The town of Metsovo, a centre of the Vlach population and culture, is only a few kilometers away from the study area. In order to understand the influence of the transhumant grazing on the tree stands there, the history of the grazing regime has to be taken into consideration. Many villages in the northern Pindus were founded or expanded only between the fifteenth and seventeenth centuries, reaching their highest populations by the end of the nineteenth century. After the Second World War (WW II) and the following civil war (until 1949), population diminished quickly and today the villages constitute only about $10 \%$ of the population they accommodated at the end of the nineteenth century (McNeill 1992). Based on the historical population figures of the Pindus villages, the high phase of transhumance (summer pasture in Pindus, winter pastures in Thessalia) is identified as the period from the late 18th to the nineteenth century. Even until WW II the flocks of the Aromuni ("Vlachs") and the nomadic Sarakatsani were still very large, numbering many tens of thousands of animals (Regel 1942; Beuermann 1967; McNeill 1992; Brandes 2007). By then erosion had already been a problem and the first protected forest areas were created in the northern Pindus during the 1930s, to ensure forest recovery (Regel 1942). The cessation of grazing together with the implementation of landscape and soil protection following the designation of the area as protected may also be co-responsible for the documented increase in annual growth during the twentyfirst century.

In the nineteenth century, wood-cutting and the sale of wood became a highly important source of income for the mountain villages of the northern Pindus as well (McNeill 1992). Many of these villages had water-powered sawmills, but it seems that this activity was mostly restricted to the easily accessible, dense forest areas of the valleys. Without roads, the trees, often having twisted wood or damaged by lightning, at higher altitudes, as in our study area, were difficult to remove. The omnipresent dead wood proves that there was no general lack of wood, not even of firewood, in the villages of the area. Obviously, the shepherds preferred an open woodland landscape to a dense forest, but the existence of very old trees in the northern Pindus reveals that the transhumant shepherds had no interest in a total destruction of all trees-since trees provided shade for the animals during the summer months.

The existence of several old trees having signs of lightning scars and the presence of internal fire scars in both cross-sections collected from dead trees and cores from living trees indicate that mature Bosnian pines may survive fires. Although tree-ring cores collected with an increment borer can be successfully used to date fires (Vasileva and Panayotov 2016), this requires special sampling (CeranoParedes et al. 2020), which was not employed in the present study. Therefore, despite recognizing the high potential of both the species and study area in terms of fire history reconstruction, we did not perform any fire history analysis.

\section{Conclusions}

Providing valuable information about past climate conditions, long Bosnian pine chronologies have been increasingly used for climate reconstructions (Klippel et al. 2018; Esper et al. 2020, 2021). Our newly developed Bosnian pine chronology from Mt. Mavrovouni, located near the village of Metsovo in northern Greece and the southernmost limit of this species, suggests that tree population dynamics from different mountains are driven by different climatic parameters, but still help capture marker years and extreme events such as the 1660 severe drought. Therefore, it would be interesting to compare mean chronologies from different mountains 
against each other regarding climate-growth relationships and to study the overall agreement of long-term growth trend among populations. This could also lead to the development of a new climate index covering a broader area while such long tree-ring series can be highly useful as reference chronologies for dating historical timber.

Our study also suggests that mature Pinus heldreichii trees can survive multiple fire events and could potentially be used for reconstructing fire history if conservation restrictions permit proper field sampling. The findings of the current study also help explain the physiognomy of high altitude stands of Bosnian pine, providing a fresh understanding of the landscape history of the northern Pindus.

Author contribution statement Conceptualization, AC, NMF, RB and TW; methodology, AC, BG-N, NMF and TW; software, AC, NMF; validation, $\mathrm{AC}, \mathrm{NMF}$ and $\mathrm{TW}$; formal analysis, AC, NMF; investigation, AC; resources, AC; data curation, $\mathrm{AC}$; writing —original draft preparation, $\mathrm{AC}, \mathrm{NMF}$, $\mathrm{RB}$; writing - review and editing, AC, NMF, BG-N, YÖ, MA, RB and TW; visualization, AC, NMF, YÖ; supervision, TW; project administration, TW; funding acquisition, TW All authors have read and agreed to the published version of the manuscript.

Supplementary Information The online version contains supplementary material available at https://doi.org/10.1007/s00468-021-02189-6.

Acknowledgements The authors would like to thank Nikos Kanelopoulos from the Forestry Department in Metsovo for his valuable help in organizing and acquiring permission for field sampling. Special thanks to Lara Klippel for providing the regional SPI reconstruction data. The authors express their deep acknowledgments to the two anonymous reviewers, the Communicating Editor and the Editor in Chief Prof. Dr. Ulrich E. Luettge for their valuable comments, which have greatly contributed to the improvement of the manuscript.

Funding This research was funded by the National Science Center, Poland, project nr 2016/22/A/HS3/00285.

\section{Declarations}

Conflict of interest The authors declare no competing interests.

Open Access This article is licensed under a Creative Commons Attribution 4.0 International License, which permits use, sharing, adaptation, distribution and reproduction in any medium or format, as long as you give appropriate credit to the original author(s) and the source, provide a link to the Creative Commons licence, and indicate if changes were made. The images or other third party material in this article are included in the article's Creative Commons licence, unless indicated otherwise in a credit line to the material. If material is not included in the article's Creative Commons licence and your intended use is not permitted by statutory regulation or exceeds the permitted use, you will need to obtain permission directly from the copyright holder. To view a copy of this licence, visit http://creativecommons.org/licenses/by/4.0/.

\section{References}

Akkemik Ü, D’Arrigo R, Cherubini P, Köse N, Jacoby GC (2008) Treering reconstructions of precipitation and streamflow for northwestern Turkey. Int J Climatol 28(2):173-183

Akkemik Ü, Dağdeviren N, Aras A (2005) A preliminary reconstruction (A.D. 1635-2000) of spring precipitation using oak tree rings in the western Black Sea region of Turkey. Int J Biometeorol 49(5):297-302. https://doi.org/10.1007/s00484-004-0249-8

Amoroso MM, Daniels LD, Baker PJ, Camarero JJ (2017) Dendroecology: tree-ring analyses applied to ecological studies; ecological studies analysis and synthesis. Springer, Berlin/Heidelberg, Germany

Baisan CH, Swetnam TW (1990) Fire history on a desert mountain range: rincon mountain wilderness, Arizona. USA Can J for Res 20:1559-1569. https://doi.org/10.1139/x90-208

Beguería S, Vicente-Serrano SM (2017) SPEI: Calculation of the Standardised Precipitation-Evapotranspiration Index. R package version 1.7. https://CRAN.R-project.org/package=SPEI

Bergeron Y, Denneler B, Charron D, Girardin M (2002) Using dendrochronology to reconstruct disturbance and forest dynamics around Lake Duparquet, northwestern Quebec. Dendrochronologia 20(1-2):175-189. https://doi.org/10.1078/1125-7865-00015

Beuermann A (1967) Fernweidewirtschaft in Südosteuropa. Westermann, Braunschweig

Borgaonkar HP, Sikder AB, SomaruRam, (2011) High altitude forest sensitivity to the recent warming: a tree-ring analysis of conifers from Western Himalaya. India Quat Int 236(1-2):158-166. https://doi.org/10.1016/j.quaint.2010.01.016

Brandes R (2007) Waldgrenzen griechischer Hochgebirge. Unter besonderer Berücksichtigung des Taygetos, Südpeloponnes (Walddynamik, Tannensterben, Dendrochronologie). Dissertation, University of Erlangen-Nuernberg, Germany - Erlanger Geographische Arbeiten, Sonderband 36. http://nbn-resolving. de/urn:nbn:de:bvb:29-opus-5410

Brandes R (2009) Dendrochronology on Pinus nigra in the Taygetos mountains, southern Peloponnisos. In: Manning SW, Bruce MJ (eds) Tree-rings, Kings, and Old World Archaeology and Environment (Papers presented in honor of Peter Ian Kuniholm). Oxford, UK, pp 81-95

Brown PM, Kaufmann MR, Shepperd WD (1999) Long-term, landscape patterns of past fire events in a montane ponderosa pine forest of central Colorado. Landsc Ecol 14:513-532

Buckley BM, Hansen KG, Griffin KL, Schmiege S, Oelkers R, D’Arrigo RD, Stahle DK, Davi N, Nguyen TQT, Le Nam C, Wilson RJS (2018) Blue intensity from a tropical conifer's annual rings for climate reconstruction: an ecophysiological perspective. Dendrochronologia 50:10-22. https://doi.org/10. 1016/j.dendro.2018.04.003

Bunn A, Korpela M, Biondi F, Campelo F, Mérian P, Qeadan F, Zang C (2020) dplR: Dendrochronology Program Library in R. R package version 1.7.1, https://CRAN.R-project.org/package $=$ dplR

Campbell R, McCarroll D, Loader NJ, Grudd H, Robertson I, Jalkanen R (2007) Blue intensity in Pinus sylvestris tree-rings: developing a new palaeoclimate proxy. Holocene 17:821-828. https://doi.org/ 10.1023/A:1008137005355

Cerano-Paredes J, Iniguez JM, Villanueva-Díaz J, Cervantes- Martínez R, Cambrón-Sandoval VH, Estrada-Arellano JR, EsquivelArriaga G, Franco-Ramos O, Vázquez-Selem L, Cardoza- Martínez GF (2020) Using tree-rings to reconstruct fire history information from forested areas. J vis Exp 164:e61698. https:// doi.org/10.3791/61698

Christopoulou A, Fulé PZ, Andriopoulos P, Sarris D, Arianoutsou M (2013) Dendrochronology-based fire history of Pinus nigra forests 
in Mount Taygetos, Southern Greece. For Ecol Manag 293:132139. https://doi.org/10.1016/j.foreco.2012.12.048

Christopoulou A, Mallinis G, Vassilakis E, Farangitakis G-P, Fyllas NM, Kokkoris G, Arianoutsou M (2019) Assessing the impact of different landscape features on post-fire forest recovery with multi-temporal remote sensing data: the case of Mount Taygetos (southern Greece). Int J Wildland Fire 28(7):521-532. https://doi. org/10.1071/WF18153

Cook ER, Kairiukstis LA (1990) Methods of dendrochronology: applications in the environmental sciences. Springer, New York

Cook ER, Anchukaitis KJ, Buckley BM, D’Arrigo RD, Jacoby GC, Wright WE (2010) Asian monsoon failure and megadrought during the last millennium. Science 328:486-489. https://doi.org/10. 1126/science. 1185188

Cook BI, Anchukaitis KJ, Touchan R, Meko DM, Cook ER (2016) Spatiotemporal drought variability in the Mediterranean over the last 900 years. J Geophys Res Atmos 121:2060-2074. https://doi. org/10.1002/2015JD023929

Cook ER, Solomina O, Matskovsky V, Cook BI, Agafonov L, Berdnikova A, Dolgova E, Karpukhin A, Knysh N, Kulakova M, Kuznetsova V, Kyncl T, Kyncl J, Maximova O, Panyushkina I, Seim A, Tishin D, Ważny T, Yermokhin M (2020) The European Russia Drought Atlas (1400-2016 CE). Clim Dyn 54:2317-2335. https:// doi.org/10.1007/s00382-019-05115-2

Cook ER, Seager R, Kushnir Y, Briffa KR, Buntgen U, Frank D, Krusic PJ, Tegel W, van der Schrier G, Andreu-Hayles L, Baillie M, Baittinger C, Bleicher N, Bonde N, Brown D, Carrer M, Cooper R, Cufar K, Dittmar C, Esper J, Griggs C, Gunnarson B, Gunther B, Gutierrez E, Haneca K, Helama S, Herzig F, Heussner K-U, Hofmann J, Janda P, Kontic R, Kose N, Kyncl T, Levanic T, Linderholm H, Manning S, Melvin TM, Miles D, Neuwirth B, Nicolussi K, Nola P, Panayotov M, Popa I, Rothe A, Seftigen K, Seim A, Svarva H, Svoboda M, Thun T, Timonen M, Touchan R, Trotsiuk V, Trouet V, Walder F, Wazny T, Wilson R, Zang C (2015) Old World megadroughts and pluvials during the Common Era. Sci. Adv. doi: https://doi.org/10.1126/sciadv.1500561

Dulamsuren C, Hauck M, Kopp G, Ruff M, Leuschner C (2017) European beech responds to climate change with growth decline at lower, and growth increase at higher elevations in the center of its distribution range (SW Germany). Trees 31(2):673-686. https:// doi.org/10.1007/s00468-016-1499-x

Esper J, Krusic PJ, Ljungqvist FC, Luterbacher J, Carrer M, Cook E, Davi NK, Hartl-Meier C, Kirdyanov A, Konter O, Myglan V, Timonen M, Treydte K, Trouet V, Villalba R, Yang B, Büntgen U (2016) Ranking of tree-ring based temperature reconstructions of the past millennium. Quat Sci Rev 145:134-151. https://doi.org/ 10.1016/j.quascirev.2016.05.009

Esper J, Klippel L, Krusic PJ, Konter O, Raible ChO, Xoplaki E, Luterbacher J, Büntgen U (2020) Eastern Mediterranean summer temperatures since $730 \mathrm{CE}$ from Mt. Smolikas Tree-Ring Densities Clim Dyn 54:1367-1382. https://doi.org/10.1007/ s00382-019-05063-x

Esper J, Konter O, Klippel L, Krusic PJ, Büntgen U (2021) Pre-instrumental summer precipitation variability in northwestern Greece from a high-elevation Pinus heldreichii network. Int J Climatol 41:2828-2839. https://doi.org/10.1002/joc.6992

Fay N, de Berker N (2018) A review of the theory and practice of tree coring on live ancient and veteran trees. Scottish Natural Heritage Research Report No. 789

Flannigan MD, Wotton BM, Marshall GA, de Groot WJ, Johnston J, Jurko N, Cantin AS (2015) Fuel moisture sensitivity to temperature and precipitation: climate change implications. Clim Change 134:59-71. https://doi.org/10.1007/s10584-015-1521-0

Fritts HC (1976) Tree rings and climate. Blackburn Press, Caldwell, New York
Fulé PZ, Ribas M, Gutiérrez E, Vallejo R, Kaye MW (2008) Forest structure and fire history in an old Pinus nigra forest eastern Spain. For Ecol Manage 255:1234-1242. https://doi.org/10. 1016/j.foreco.2007.10.046

Fyllas NM, Christopoulou A, Galanidis A, Michelaki CZ, Giannakopoulos C, Dimitrakopoulos PG, Arianoutsou M, Gloor M (2017a) Predicting species dominance shifts across elevation gradients at mountain forests in Greece under a warmer and drier climate. Reg Environ Change 17:1165-1177. https://doi.org/10.1007/ s10113-016-1093-1

Fyllas NM, Christopoulou A, Galanidis A, Michelaki CZ, Giannakopoulos C, Dimitrakopoulos PG, Fulé PZ, Arianoutsou M (2017b) Tree growth-climate relationships in a forest-plot network on Mediterranean mountains. Sci Total Environ 598:393-403. https:// doi.org/10.1016/j.scitotenv.2017.04.145

Golodets C, Sternberg M, Kigel J, Boeken B, Henkin Z, Seligman NG, Ungar ED (2013) From desert to Mediterranean rangelands: will increasing drought and inter-annual rainfall variability affect herbaceous annual primary productivity? Clim Change 119:785-798. https://doi.org/10.1007/s10584-013-0758-8

Grolemund G, Wickham H (2011) Dates and times made easy with lubridate. J. Stat. Softw 40(3):1-25. https://www.jstatsoft.org/ v40/i03/

Harley GL, Baisan CH, Brown PM, Falk DA, Flatley WT, GrissinoMayer HD, Hessl A, Heyerdahl EK, Kaye MW, Lafon CW, Margolis EQ, Maxwell RS, Naito AT, Platt WJ, Rother MT, Saladyga T, Sherriff RL, Stachowiak LA, Stambaugh MC, Sutherland EK, Taylor AH (2018) Advancing dendrochronological studies of fire in the United States. Fire 1:11. https://doi.org/10.3390/fire1010011

Horák J (2017) Insect ecology and veteran trees. J Insect Conserv 21:1-5. https://doi.org/10.1007/s10841-017-9953-7

Kassambara A (2017) ggpubr: 'ggplot2' Based Publication Ready Plots. R package version 0.1.6. https://CRAN.R-project.org/packa ge $=$ ggpubr

Keane RE, Agee JK, Fulé P, Keeley JE, Key C, Kitchen SG, Miller R, Schulte LA (2008) Ecological effects of large fires on US landscapes: benefit or catastrophe? A. IJWF 17:696-712. https://doi. org/10.1071/WF07148

Klesse S, Ziehmer M, Rousakis G, Trouet V, Frank D (2015) Synoptic drivers of 400 years of summer temperature and precipitation variability on Mt. Olympus. Greece Clim Dyn 45:807-824. https:// doi.org/10.1007/s00382-014-2313-3

Klippel L, Krusic PJ, Brandes R, Hartl-Meier C, Trouet V, Meko M, Esper J (2017) High-elevation inter-site differences in Mount Smolikas tree-ring width data. Dendrochronologia 44:164-173

Klippel L, Krusic PJ, Brandes R, Hartl C, Belmecheri S, Dienst M, Esper J (2018) A 1286-year hydro-climate reconstruction for the Balkan Peninsula. Boreas 47(4):1218-1229. https://doi.org/10. 1111/bor. 12320

Konter O, Krusic PJ, Trouet VM, Esper J (2017) Meet Adonis, Europe's oldest dendrochronologically dated tree. Dendrochronologia 42:12. https://doi.org/10.1016/j.dendro.2016.12.001

Kuniholm PI (1990) Archaeological evidence and non-evidence for climatic change. In: Runcorn SJ, Peckers J-C (eds) The Earth's Climate and Variability of the Sun Over Recent Millennia. Philosophical Transactions of the Royal Society of London. pp. 645-655

Levanič T, Popa I, Poljanšek S, Nechita C (2013) A 323-year long reconstruction of drought for SW Romania based on black pine (Pinus nigra) tree-ring widths. Int J Biometeorol 57(5):703-714

Liu Q, Piao S, Janssens IA, Fu Y, Peng S, Lian X, Ciais P, Myneni RB, Peñuelas J, Wang T (2018) Extension of the growing season increases vegetation exposure to frost. Nat Commun 9:26. https:// doi.org/10.1038/s41467-017-02690-y

Management Agency of Vikos-Aoos \& Pindos National Park (2017) Discovering Northern Pindos. p. 26. https://www.pindosnationalp 
ark.gr/wp-content/uploads/2020/09/Discovering-Pindos_2017_ EN.pdf. Accessed 06 Jan 2021

Mazarzhanova K, Kopabayeva A, Köse N, Akkemik Ü (2017) The first forest fire history of the Burabai Region (Kazakhstan) from tree rings of Pinus sylvestris. Turk J Agric for 41:165-174. https://doi. org/10.3906/tar-1610-72

McNeill J (1992) The Mountains of the Mediterranean World (Studies in Environment and History). Cambridge University Press Cambridge. https://doi.org/10.1017/CBO9780511529023

Molina-Terrén D. Fry D, Grillo F, Cardil A, Stephens S (2016) Fire history and management of Pinus canariensis forests on the western Canary Islands Archipelago, Spain. For Ecol Manag 382:184192. https://doi.org/10.1016/j.foreco.2016.10.007

Morales MS, Cook ER, Barichivich J, Christie DA, Villalba R, LeQuesne C, Srur AM, Ferrero ME, González-Reyes A, Couvreux F, Matskovsky V, Aravena JC, Lara A, Mundo IA, Rojas F, Prieto MR, Smerdon JE, Bianchi LO, Masiokas MH, Urrutia-Jalabert R, Rodriguez-Catón M, Muñoz AA, Rojas-Badilla M, Alvarez C, Lopez L, Luckman BH, Lister D, Harris I, Jones PD, Williams AP, Velazquez G, Aliste D, Aguilera-Betti I, Marcotti E, Flores F, Muñoz T, Cuq E, Boninsegna JA (2020) Six hundred years of South American tree rings reveal an increase in severe hydroclimatic events since mid-20th century. PNAS 202002411. https:// doi.org/10.1073/pnas.2002411117

Panayotov M, Bebi P, Trouet V, Yurukov S (2010) Climate signal in tree-ring chronologies of Pinus peuce and Pinus heldreichii from the Pirin Mountains in Bulgaria. Trees 24:479-490

Panzac D (1985) La peste dans I'empire Ottoman 1700-1850. Editions Peeters, Louvain

Piovesan G, Biondi F, Baliva M, Presutti Saba E, Calcagnile L, Quarta G, D’Elia M, De Vivo G, Schettino A, Di Filippo A (2018) The oldest dated tree of Europe lives in the wild Pollino massif: Italus, a strip-bark Heldreich's pine. Ecology 99(7):1682-1684. https:// doi.org/10.1002/ecy.2231

Pretzsch H, Hilmers T Uhl E, Bielak K, Bosela M, del Río M, Tognetti R (2021) European beech stem diameter grows better in mixed than in mono-specific stands at the edge of its distribution in mountain forests. Eur J Forest Res 140:127-145. https://doi.org/ 10.1007/s10342-020-01319-y

Purgstall BJVH (1983) Ottoman State History Vol. 1-7, Translator: Vecdi Bürün, Üçdal Publishing, Istanbul (in Turkish)

R Core Team (2020) R: A language and environment for statistical computing. R Foundation for Statistical Computing, Vienna, Austria. https://www.R-project.org/

Regel C (1942) Kreuz und quer durch den Pindus. Mitt D Deutschen Dendrologischen Gesellschaft 55:259-283

Sarris D, Christopoulou A, Angelonidi E, Koutsias N, Fulé PZ, Arianoutsou M (2014) Increasing extremes of heat and drought associated with recent severe wildfires in southern Greece. Reg Environ Change 14:1257-1268. https://doi.org/10.1007/ s10113-013-0568-6

Seim A, Buntgen U, Fonti P, Haska H, Herzig F, Tegel W, Trouet V, Treydte K (2012) Climate sensitivity of a millennium-long pine chronology from Albania. Climate Res 51:217-228. https://doi. org/10.3354/cr01076

Soltani A, Sadeghi Kaji H, Kahyani S (2020) Effects of different landuse systems (grazing and understory cultivation) on growth and yield of semi-arid oak coppices. J for Res 31:2235-2244. https:// doi.org/10.1007/s11676-019-01063-z

Stokes MA, Smiley TL (1996) An Introduction to tree-ring dating. The University of Arizona Press, Tucson

Sullivan PF, Pattison RR, Brownlee AH, Cahoon SMP, Hollingsworth TN (2016) Effect of tree-ring detrending method on apparent growth trends of black and white spruce in interior Alaska. Environ Res Lett 11:114007. https://doi.org/10.1088/1748-9326/11/ $11 / 114007$
Tejedor E, de Luis M, Cuadrat JM, Esper J, Saz MA (2016) Treering-based drought reconstruction in the Iberian Range (east of Spain) since 1694. Int J Biometeorol 60:361-372. https://doi.org/ 10.1007/s00484-015-1033-7

Todaro L, Andreu L, D’Alessandro CM, Gutirrez E, Cherubinic P, Saracino A (2007) Response of Pinus leucodermis to climate and anthropogenic activity in the National Park of Pollino (Basilicata, Southern Italy). Biol Conserv 137:507-519. https://doi.org/10. 1016/j.biocon.2007.03.010

Touchan R, Funkhouser G, Hughes MK, Erkan N (2005a) Standardized precipitation index reconstructed from Turkish ring widths. Clim Change 72:339-353. https://doi.org/10.1007/s10584-005-5358-9

Touchan R, Xoplaki E, Funkhouser G, Luterbacher J, Hughes MK, Erkan N, Akkemik Ü, Stephan J (2005b) Reconstruction of spring/summer precipitation for the Eastern Mediterranean from tree-ring widths and its connection to large-scale atmospheric circulation. Clim Dyn 25(1):75-98. https://doi.org/10.1007/ s00382-005-0016-5

Touchan R, Akkemik Ü, Hughes MK, Erkan N (2007) May-June precipitation reconstruction of southwestern Anatolia, Turkey during the last 900 years from tree rings. Quat Res 68(2):196-202

Touchan R, Anchukaitis KJ, Shishov VV, Sivrikaya F, Attieh J, Ketmen M, Stephan J, Mitsopoulos I, Christou A, Meko DM (2014a) Spatial patterns of Eastern Mediterranean climate influence on tree growth. The Holocene 24(4):381-392. https://doi.org/10.1177/ 0959683613518594

Touchan R, Meko DM, Anchukaitis KJ (2014b) Dendroclimatology in the Eastern Mediterranean. Radiocarbon 56(4):S61-S68. https:// doi.org/10.2458/azu_rc.56.18321

Touchan R, Baisan CH, Mitsopoulos ID, Dimitrakopoulos AP (2012) Fire history in European black pine (Pinus nigra Arn.) forests of the Valia Kalda, Pindus mountains, Greece. Tree Ring Res. 68(1):45-50. https://doi.org/10.3959/2011-12.1

Trouet V, Panayotov MP, Ivanova A, Frank D (2012) A pan-European summer teleconnection mode recorded by a new temperature reconstruction from the northeastern Mediterranean (AD 17682008). Holocene 22:887-898. https://doi.org/10.1177/09596 83611434225

Tsvetanov N, Dolgova E, Panayotov M (2020) First measurements of blue intensity from Pinus peuce and Pinus heldreichii tree rings and potential for climate reconstructions. Dendrochronologia 60:125681. https://doi.org/10.1016/j.dendro.2020.125681

Vasileva P, Panayotov M (2016) Dating fire events in Pinus heldreichii forests by analysis of tree ring cores. Dendrochronologia 38:98-102. https://doi.org/10.1016/j.dendro.2016.04.001

Venables WN, Ripley BD (2002) Modern applied statistics with S, 4th edn. Springer, New York

Vitali A, Garbarino M, Camarero JJ, Malandra F, Toromani E, Spalevic V, Curovic M, Urbinati C (2019) Pine recolonization dynamics in Mediterranean human-disturbed treeline ecotones. For Ecol Manag 435:28-37. https://doi.org/10.1016/j.foreco.2018.12.039

Wickham H (2017) tidyverse: easily install and load the 'tidyverse'. $\mathrm{R}$ package version 1.2.1. https://CRAN.R-project.org/package $=$ tidyverse

Wigley TML, Briffa KR, Jones PD (1984) On the average value of correlated time series, with applications in dendroclimatology and hydrometeorology. J Clim Appl Meteorol 23:201-213. https://doi. org/10.1175/1520-0450(1984)023\%3c0201:OTAVOC\%3e2.0.CO;2

Williams AP, Michaelsen J, Leavitt SW, Still CJ (2010) Using tree rings to predict the response of tree growth to climate change in the continental united states during the twenty-first century. Earth Interact 14:1-20. https://doi.org/10.1175/2010EI362.1

Zhang T (2005) Influence of the seasonal snow cover on the ground thermal regime: an overview. Rev Geophys 43:RG4002. https:// doi.org/10.1029/2004RG000157 
Żywiec M, Muter E, Zielonka T, Delibes M, Calvo G, Fedriani JM (2017) Long-term effect of temperature and precipitation on radial growth in a threatened thermo-Mediterranean tree population. Trees 31:491-501. https://doi.org/10.1007/s00468-016-1472-8
Publisher's Note Springer Nature remains neutral with regard to jurisdictional claims in published maps and institutional affiliations. 